\title{
Not less but more livestock for sustainability in southern Mali! A modelling study of the balance between soil organic matter, livestock, crop residues and leys
}

\author{
RH Bosma 1, M Bos 2, S Kanté 1, D Kébé 1 \\ 'Equipe Systemes de Production et Gestion des Ressources Naturelles, BP 186, Sikasso, Mali; 2Jan Steenlaan \\ 28-1, 3904 XS Veenendaal. Netherlands
}

The continuation of traditional farming techniques in southern Mali will lead to an ecological disaster in the near future. Commonly, development agents say the grazing pressure is too high and propose a reduction of livestock herds. But the restitution of organic matter (OM) through livestock manure and the roots of leys can reduce soil mining. It is hypothezed that an increase in animal density will lead to improve sustainability and that intensive crop residue use is crucial (Bosma et al, 1993, International conference : Elevage et cycle viable des élements nutritifs dans les systèmes mixtes agriculture-élevage de l'Afrique subsaharienne, CIPEA/ILCA, Addis Abeba, 17).

Building on Bosma et a/ (1993), this paper develops a model in which the demand and supply of $\mathrm{OM}$ and feed are specified in richer detail. Labour and economic efficiency are included, but labour requirements remain the main constraints in the model. The feasibility of the proposed system changes will be discussed with reference to maintaining actual soil OM levels of villages in the Sudanian and Sudano-guinean agro-ecological zones.

Animal husbandry systems are classified according to the intensity of manure "production". Crop residues can be applied as bedding to decompose along with manure especially in the humid season, and/or used as fodder during the dry season. Feeding strategies indicate the extent of fodder production and range land grazing is based on frequency schemes.
Livestock are taken into account as tropical livestock units of $250 \mathrm{~kg} \mathrm{LW}$.

Sustaining the OM balance is an arduous task in current extensive systems even with maximum animal densities and the introduction of leys. Obtaining an $O M$ equilibrium requires intensive use of crop residues for bedding and an expansion of the current herds by 65 to $225 \%$. Consequently, animal densities will increase to between 60 and $99 \%$ of the systems carrying capacity. As it is less profitable than other systems, dry season zerograzing needs to be reserved for productive animals like draught oxen and dairy cows. In the model, Crude Protein and Total Digestible Nutrient values don't limit carrying capacity in the dry season, which is in contrast with reality. This is likely due to an overestimation of selective range use.

The use of crop residues and a maximum of $16 \%$ of leys is profitable and reduces transport of fertility from range to fields by $50-75 \%$. Feeding maize straw in the dry season increases income slightly $(<3 \%)$, whereas the use of leys for both grazing and fodder achieves the maximum potential income. Changing the cropping pattern can reduce the decline of the OM balance, increase income, decrease labour demand and enable crop diversification. In particular, to promote diversification the area cropped in millet and sorghum should decrease by $40 \%$ in the Sudanian zone and by $75 \%$ in the Sudanoguinean region and substited with maize, peanuts and stylo leys. 